\author{
A.D. Nasyrkhanov ${ }^{1}$, B.M. Iskakov ${ }^{2, *}$ \\ ${ }^{1}$ International Business Academy (AlmaU), Kazakhstan \\ ${ }^{2}$ University «Turan-Astana», Kazakhstan \\ 'arsen.nassyrkhanov@roche.com, ${ }^{2}$ iskakov82@mail.ru \\ ${ }^{1}$ https://ORCID 0000-0001-9573-6499, ${ }^{2}$ http://ORCID 0000-0002-3989-7631
}

\title{
Investment policy in the tourism sector of Kazakhstan
}

\begin{abstract}
Object:The object of the study is to develop a set of methodological, scientific and practical recommendations on ensuring the investment attractiveness of the tourism sector in Kazakhstan.

Methods:Methods of economic and comparative analysis, classification were used in this article, economic and statistical methods were used to process information.

Results: The results of the study confirm the effectiveness of tourism development in the context of globalization. The Republic of Kazakhstan is an attractive country for investing not only in raw materials production, but also in the service sector. Over the years of independence, the economy of Kazakhstan has risen significantly, the well-being of the people has increased, and the quality of life has noticeably improved. Kazakhstanis began to pay more attention to the quality of leisure. Thus, the tourism industry has been singled out as a separate promising cluster of the republic, because Kazakhstan has the potential to develop this cluster.

Conclusions: The article discusses the problems and prospects of the development of investment policy in the tourism industry. The authors identified the main directions of state participation in the investment process, aimed at the development of the tourism sector. The authors analysed scientific approaches to certain problems of the development and functioning of the tourism industry. Conclusions are drawn on the possibility of applying foreign experience in the tourism industry of Kazakhstan.
\end{abstract}

Keywords: tourism industry; travel business; tourism infrastructure; travel agency; transnationalization; state investment policy.

\section{Introduction}

The tourism industry in modern conditions significantly affects the development of the global economy. In most countries of the world, a significant part of the welfare of the state is based on income from the organization tourism activities. Due to economic growth, increasing the cultural and material level of the population, increasing free time, tourism claims to be the leading export industry in the world. For the successful development of the tourism industry, it is necessary to create a competitive industry that provides growing consumer demand and makes a significant contribution to the socio-economic development of countries.

The main issue that all enterprises are facing is the issue of attracting additional financial resources that can satisfy investment needs. There are many ways to resolve this issue: obtaining a commercial loan from a bank, corporatization, trading in futures contracts, implementing franchising projects, and foreign lending. The most commonly used way to meet investment needs includes foreign investment.

The purpose of this study is to emphasize the importance of attracting investments as a strategic goal of tourism development in Azerbaijan and to indicate ways to improve investment investments in tourism. In general, the investment process is an environment-specific process of introducing an investor to an investee, which is carried out in order to obtain a managed investment income through investment. Investments in the tourism industry should be considered as the use of financial resources in the form of long-term investments in it in order to obtain the desired return on investment both domestically and abroad.

Factors that encourage investment attraction may be different: a desire to increase sales and services in tourism; the need to update and improve the existing material and technical base (for example, improving equipment, introducing a modern reservation system); the desire to develop new types of activities (entering the market of the tourism industry with a new tourism product or a new type of service). These factors emphasize the importance of investments in creating an economic base for solving social and economic problems.

\footnotetext{
* Corresponding author.

E-mail address: iskakov82@mail.ru
} 
Investment is any type of property, including cash, securities, equipment and results of intellectual activity, owned by the investor under the right of ownership or other property rights, and property rights invested by the investor in the objects of investment activity in order to obtain profit (income) and (or) achieving another meaningful result.

Investing in tourism is the allocation of investor capital in the tourism business in order to make a profit. Since capital is one of the main factors of production, the tourism industry's ability to conduct products directly depends on the capital invested.

At the level of an individual tourism enterprise (company), investments are financial investments of specific individuals or legal entities in the development of this enterprise. At the same time, both own and borrowed funds can be invested.

In order to increase the flow of foreign investment in the economy, it is necessary to create a favorable investment climate. The investment climate is a combination of political, economic, legal, social, domestic, climatic, natural, infrastructural and other factors that determine the degree of risk of investment and the possibility of their effective use.

The investment attractiveness of the territories acts as a determining factor in choosing the investment object. Indeed, in the face of the resource requirements of some market participants and the ability and desire to invest temporarily available funds of others when concluding a transaction between them, investment attractiveness should be considered as a key category.

In Western economic literature, the concept of "investment opportunity" is used to characterize the favorable external environment (relative to the investment object) for investing in this object in the present time period.

They assess the investment attractiveness of the region on the basis of a "prediction" of economic returns (the level of return on invested funds is estimated) and an analysis of the riskiness of investments.

\section{Literaturereview}

From the point of view of Airey, D., \&Ruhanen investment potential takes into account basic macroand microeconomic indicators, saturation with production factors (natural resources, labour, fixed assets, infrastructure, etc.), consumer demand, etc (Airey, D., \&Ruhanen, 2014).

Based on the statements of scientists about the nature of the investment potential of the region, we can come to the conclusion that the following components are involved in its formation: natural resource component, geographical component, economic component, infrastructure component, institutional component, labor force, scientific and technical potential, consumer component, manufacturing component.

Each of these components consists of a number of indicators characterizing the effectiveness of the functioning of regions as economic systems and investment objects.

Assessing investment potential, the following system of macroeconomic indicators should be used:

- the dynamics of investment and GDP (allows you to determine the degree of crisis in the investment sphere and its impact on the level of business activity);

- dynamics of production in certain sectors of the economy (especially in industry);

- change in the rate of accumulation of GDP;

- structure of the accumulation fund;

- the dynamics of the rate of accumulation and the process of reproduction of fixed capital (the share of the costs of replacing (reimbursing) fixed assets and their expansion);

- the dynamics of the ratio of investments in fixed assets (taking into account the costs of major repairs) and the annual disposal of funds, which characterizes the type of reproduction - simple, expanded or narrowed;

- level of load of the production capacity (characterizes the use of production potential).

Based on a comprehensive analysis of the region's investment potential, programs are being developed to increase its investment attractiveness (Chang, W., \&Katrichis, J.M, 2016).

\section{Methods}

The methods for evaluating investment projects may not beunified in all cases, since investment tourist projects vary greatly in scale of costs, terms of its use, and helpful results. For small investment projects that do not require large capital investments, do not significantly affect the change in the output of tourism products (tourism services), and also have a relatively short useful life, the simplest calculation methods can be applied. 
The investment process is always associated with risk. Investment risk implies the likelihood of financial loss. Its elements are: legislative, political, economic, financial, social, managerial, criminal,and environmental risks.

The risk of investment activity is assessed using objective methods based on the analysis of statistical data and subjective methods based on the assessment of experts and various specialists.

Summarizing the foregoing, we can conclude that high investment attractiveness is the main factor influencing the achievement of high and sustainable rates of socio-economic growth and contributing to the acquisition of a competitive status by the region. Given the limited investment resources, on the one hand, and a large selection of investment objects of varying degrees of attractiveness, on the other hand, the development of an investment strategy is necessary in order to strategically manage the activities of a tourism company.

Investment strategy implies a long-term focused plan of action of the enterprise to create an effective investment structure, as well as ways to achieve maximum profit from investment activities. The main objective of the investment strategy in tourism is to achieve high investment efficiency aimed at developing tourism enterprises and ensuring their competitiveness.

Therefore, ensuring the effectiveness of investment investments should be a priority when developing a system for managing investment processes in the tourism industry. It is known that the condition for the effective functioning of this system is to increase the scientific feasibility of management decisions in the field of investment, to ensure the interaction of such basic elements of the management system as principles, methods, management functions and tools that guide the implementation of investment projects to achieve the necessary results and level of effectiveness.

\section{Results}

The dynamic development of the tourism industry depends on the importance that the state attaches to it, that is, on the provision of state support.

In order to attract private, including foreign investment in the tourism industry, next points are significant:

- the activity of local authorities in the field of advertising and information activities (coverage of the tourist and recreational potential of the territorial-administrative unit);

- liberal administrative and tax policies encouraging private investment initiative;

- an effective antitrust and anti-criminal policy of local authorities aimed at maintaining a healthy competitive environment among tourism enterprises (Sainaghi, R., \& Baggio, R, 2017).

The volume of investments in the reconstruction and construction of campsites, hotels and restaurants is increasing annually .

Table -1 Investments in fixed assets by ownership in the tourism sector in 2019

\begin{tabular}{|c|c|c|c|c|}
\hline \multirow{3}{*}{ The field of operation } & \multicolumn{4}{|c|}{ Type of ownership, million tenge } \\
\hline & \multirow[b]{2}{*}{ State } & \multirow[b]{2}{*}{ Private } & \multirow{2}{*}{$\begin{array}{l}\text { form them } \\
\text { joint ventures } \\
\text { with foreign } \\
\text { participation }\end{array}$} & \multirow{2}{*}{$\begin{array}{l}\text { other states, } \\
\text { their legal } \\
\text { entities and } \\
\text { citizens }\end{array}$} \\
\hline & & & & \\
\hline All & 67352,7 & 169770,1 & 19881,4 & 9322,5 \\
\hline Activities of travel agencies & - & 65,0 & 0,3 & 0,3 \\
\hline Hotel and restaurant services & 2223,9 & 18005,2 & 3182,6 & 6118,9 \\
\hline Activities of medical/resort facilities & 8960,4 & 3681,2 & 2,0 & - \\
\hline Organization of leisure and entertainment, culture and sports & 17772,5 & 5230,5 & 1203,1 & - \\
\hline Roads construction, airfields and sports facilities & 937,8 & 10471,8 & 727,2 & 1876,3 \\
\hline Land transport & 31019,8 & 108740,6 & 57,1 & 595,4 \\
\hline Water transport & 1,0 & 13611,4 & 6097,9 & 53,5 \\
\hline Air transport & 6437,3 & 9964,4 & 8611,2 & 678.1 \\
\hline
\end{tabular}


The volume of investments in 2019 in the activities of campsites increased 142 times in compresence to 2018 .

A decrease in the volume of financial investments in 2019, in compresence with 2018, is noted in the activities of hotels with restaurants - by $41 \%$; hotels without restaurants - by $27 \%$; youth tourist camps and mountain tourist camps - by $44 \%$; restaurants and bars - by $23 \%$.

\section{Discussions}

The state needs to direct the investment policy to the development of the investment potential of the territories, the infrastructure involved in the investment process; on the further development and deepening of investment processes taking place on the territory; to improve the current investment legislation; on the most efficient use of budget investments; to create favourable conditions for investors; to ensure the development of the information infrastructure of the regions. Thus, the state investment policy should take into account the need to create favourable socio-economic conditions in the regions, ensure the profitability of travel agencies, balance the foreign economic activity of the state, and improve the quality of life of the population. Currently, the highest investment activity in the tourism sector is noted in those regions where tourism has been declared a priority and socially significant type of entrepreneurial activity.

Azerbaijan has managed to achieve the status of one of the most promising countries in the world with the potential for long-term growth in the tourism market. The development concept "Azerbaijan 2020: A Look into the Future" envisages the development of tourism infrastructure, expanding the scope of tourism services that meet international standards, increasing the competitiveness of this industry and increasing its share in GDP. In order to develop tourism, it is planned to improve legislation and standards in the tourism sector, as well as stimulate tourism activities in the regions (Helmy, E.M2014).

According to the State Statistics Committee, in 2019 the share of tourism (599.2 million man.) In the country's GDP (50.069 billion man.) Increased to 1.2\% from $0.99 \%$ in 2018 (422.7 million . and 42.465 billion manat, respectively).

In 2019 , the share of tourism in total investments in the country's economy (12.776 billion manats) amounted to $1.6 \%$, or 209.8 million manats.

Azerbaijan has managed to transform the direction of foreign investment in the non-oil sector of the economy, having established itself as a reliable partner, as a country in which the rights of investors are protected, and where the state fulfills its obligations. Over the past 15 years, more than $\$ 60$ billion has been allocated to the non-oil sector:

- in 2018 investments in the non-oil economy almost 3 times exceeded the amount invested in the oil sector;

- more than a fifth of foreign direct investment goes to the non-oil sector;

- the growth dynamics of the non-oil economy is many times higher than the growth of the oil sector.

The country has adopted laws that protect investors' rights, confirming the inviolability of property, creating favorable working conditions for foreign entrepreneurs, and making full use of the profit they receive. It is known that in order to attract foreign investors, a simplification of the tax system is required. To this end, favorable taxation conditions are being created in Azerbaijan (the formation of the same taxation conditions for both foreign and local investors). With many countries, bilateral agreements have been concluded on the bilateral protection of investments, on the abolition of double taxation (Fayos-Solà, E. and Alvarez, M.D. 2014).

The decree of the national leader Heydar Aliyev in 2002 on the approval of the state budget provided for the possibility of using "tax holidays" for regions that are problematic from the point of view of economic development. This means that tax incentives can be replaced by "tax holidays" and tax and investment loans, which will reduce tax revenues and attract new investments into the country (Rozo Bellón, E. and Garavito González, L. 2014).

A necessary stage in the development of investment policy is the preparation of methodological tools for regional authorities, analytical organizations for the diagnosis of investment attractiveness of regional tourist and recreational areas (Ruhanen, L. and Whitford, M2014). The following principles should be based on the development of a system of balanced aggregated indicators for assessing the investment attractiveness of regional tourist and recreational zones:

- scientific validity, meaning the identification of patterns and relationships of factors affecting the investment attractiveness of regional tourist and recreational areas;

- purposefulness - subordinating the structure of indicators to clearly defined goals for assessing the investment attractiveness of regional tourist and recreational areas; 
- consistency - consideration of the tourist complex of the region, as a single object, as well as a set of complementary elements;

- the necessary diversity, characterized in that each indicator characterizes a certain side of the phenomenon, which together give an objective assessment of the investment attractiveness of regional tourist and recreational areas;

- adequacy - compliance with the real socio-economic and investment process of tourist and recreational areas of the region;

- efficiency - the possibility of making a reliable investment decision based on the resulting assessment of the investment attractiveness of regional tourist and recreational areas;

- continuity - the ability to adjust the assessment of indicators upon receipt of new data affecting the assessment of the indicator;

- verification - a systematic definition of reliability, accuracy and validity (Pathirana, D.P.U.T., \& Gnanapala, W.K.A.C, 2015).

The developed system of balanced indicators based on these principles will allow systematically and comprehensively diagnosing the investment attractiveness of regional tourist and recreational areas to compile an investment rating of regional tourist and recreational areas, which will allow potential investors to compare tourist and recreational areas of different regions or one region in terms of investment and will accelerate investment decision making process.

\section{Conclusions}

Investment strategy implies a long-term focused plan of action of the enterprise to create an effective investment structure, as well as ways to achieve maximum profit from investment activities. The main objective of the investment strategy in tourism is to achieve high investment efficiency aimed at developing tourism enterprises and ensuring their competitiveness.

Therefore, ensuring the effectiveness of investment investments should be a priority when developing a system for managing investment processes in the tourism industry. It is known that the condition for the effective functioning of this system is to increase the scientific feasibility of management decisions in the field of investment, to ensure the interaction of such basic elements of the management system as principles, methods, management functions and tools that guide the implementation of investment projects to achieve the necessary results and level of effectiveness.

The dynamic development of the tourism industry depends on the importance that the state attaches to it, that is, on the provision of state support.

We can safely say that the tourism industry is today one of the priority sectors in the economy of Kazakhstan, the state is developing projects in this direction. Based on the adopted state programs, a clear tourism development strategy exists and is being developed. The state forms the concept of a favorable tourist image of the country, determines the main areas of tourism activity, creates favorable conditions for the development of tourism.

Attracting foreign investment in the tourism industry is an integral part of the economic development strategy of the Republic of Kazakhstan. After all, it is known that along with capital, long-term foreign investments bring new tchnologies, innovations, and provide the population with new high-paying jobs(Nizhegorodcev, R.M., Ratner, S.V, 2015).

The economic development and political stability of Kazakhstan in recent years have contributed to the increase of such investments by foreign countries in the country's tourism.

The main task of the state should now be to maintain a positive trend in attracting foreign investment in tourism, and further contribute to improving the investment climate in the country.

\section{References}

Airey, D., \& Ruhanen, L. (2014). Tourism policy-making in Australia: a national and state perspective. Tourism Planningand Development, 2, 149-162.

Chang, W., \& Katrichis, J.M. (2016). A literature review of tourism management (1990-2013): a content analysis perspective. Current Issues in Tourism, 19, 791-823.

Sainaghi, R., \& Baggio, R. (2017). Complexity traits and dynamics of tourism destinations. Tourism Management, 63,368-382.

Helmy, E.M. (2014). «Political Uncertainty», Tourism as an Instrument for Development: A Theoretical and Practical Study. Bridging Tourism Theory and Practice, 2, 301-315. 
Fayos-Solà, E. \& Alvarez, M.D. (2014). «Tourism Policy and Governance for Development», Tourism as an Instrument for Development: A Theoretical and Practical Study. Bridging Tourism Theory and Practice, Vol. 5, Emerald Group Publishing Limited, 3, 101-124.

RozoBellón, E. \& Garavito González, L. (2014). «Tourism in Colombia», Tourism as an Instrument for Development: A Theoretical and Practical Study. Bridging Tourism Theory and Practice, Vol. 5, Emerald Group Publishing Limited, 211-226.

Ruhanen, L. \& Whitford, M. (2014). «Indigenous Tourism and Events for Community Development in Australia», Tourism as an Instrument for Development: A Theoretical and Practical Study. Bridging Tourism Theory and Practice, Vol. 5, Emerald Group Publishing Limited, 183-194.

Pathirana, D.P.U.T., \& Gnanapala, W.K.A.C. (2015). Tourist Harassment at Cultural Sites in Sri Lanka. Tourism, Leisure and Global Change, 2, 42-56.

Nizhegorodcev, R.M., \& Ratner, S.V. (2015). Ekolohicheskie standarty v sfere turizma: problemy vnedreniia (na primere Krasnodarskoho kraia) [Environmental standards in the tourism sector: problems of implementation (with the example of Krasnodar region)]. Rossiiskoe predprinimatelstvo - Russian business, 16(13), 2101-2124. https://doi.org/10.18334/rp.16.13.507 [in Russian].

The Global Ecolabelling Network (2017), 28-29. view.publitas.com. Retrieved from (URL: https://view.publitas.com/global-ecolabelling-network/gen-annual-report-2017/page/1

Official site of Green Key Global (2020). greenkey.global. Retrieved from URL: https://www.greenkey.global/

Harris, R.(2018) The 2018 Green report. Hotelier. hoteliermagazine.com. Retrieved from URL: https://www.hoteliermagazine.com/the-2018-green-report

Official site of Radisson Hotel Group. radissonhotelgroup.com. Retrieved from URL: https://www.radissonhotelgroup.com/responsible-business_think-planet

Official site of the United Nations. un.org. Retrieved from URL: https://www.un.org/sustainabledevelopment/

Official site of Leef life (2020). ecounion.ru. Retrieved from URL: https://ecounion.ru/wpcontent/uploads/2019/12/sredstva-razmeshenia.pdf

\section{А.Д. Насырханов, Б.М. Искаков}

\section{Қазақстанның туризм саласындағы инвестициялық саясаты}

\section{Андатпа}

Maқcambl: Зерттеудің мақсаты Қазақстандағы туризм саласының инвестициялық тартымдылығын қамтамасыз ету бойынша әдістемелік және ғылыми-практикалық ұсыныстар кешенін әзірлеу.

Әдістері: Жазу кезінде экономикалық және салыстырмалы талдау, жіктеу, ақпаратты өңдеу үшін экономикалық-статистикалық әдістері қолданылған.

Kopblmынды: Зерттеу нәтижелері жаһандану жағдайында туризмды дамытудың тиімділігін растайды. Қазақстан Республикасы өндірістің шикізат салаларына ғана емес, қызмет көрсету саласына да инвестициялар салу үшін тартымды ел болып табылады. Тәуелсіздік жылдары Қазақстан экономикасы көтерілді, халықтың әлауқаты артты, өмір сапасы айтарлықтай жақсарды. Қазақстандықтар демалыс сапасына көбірек көңіл бөле бастады. Мәселен, туристік индустрия республиканың жекелеген перспективалы кластеріне бөлінген, өйткені Қазақстан осы кластерді дамыту әлеуетіне ие.

Тұжырымдама: Мақалада туристік саладағы инвестициялық саясатты дамыту мәселелері мен перспективалары қарастырылған. Авторлар туристік саланы дамытуға бағытталған мемлекеттің инвестициялық процеске қатысуының негізгі бағыттарын анықтады. Туристік саланы дамыту мен қызмет етудің белгілі бір мәселелері бойынша ғылыми тәсілдер талданды. Қазақстанның туристік саласында шетелдік тәжірибені қолдану мүмкіндігі туралы қорытындылар жасалды.

Кілm сөздер: туристік сала, туристік бизнес, туристік инфрақұрылым, турагенттік, транснационализация, мемлекеттік инвестициялық саясат.

\section{А.Д. Насырханов, Б.М. Искаков \\ Инвестиционная политика в сфере туризма Казахстана}

\section{Аннотация}

Цель: Цель исследования состоит в разработке комплекса методических и научно-практических рекомендаций по обеспечению инвестиционной привлекательности сферы туризма в Казахстане.

Memoдbl: При написании статьи использованы приемы экономического и сравнительного анализа, классификации, для обработки информации применялись экономико-статистические методы. 
Pезультаты: Результаты исследования подтверждают эффективность развития туризма в условиях глобализации. Республика Казахстан является привлекательной страной для вложения инвестиций не только в сырьевые сферы производства, но и в сферу услуг. За годы независимости экономика Казахстана значительно поднялась, благосостояние народа увеличилось, заметно улучшилось качество жизни. Казахстанцы стали больше уделять внимания качеству досуга. Так, туристская индустрия выделена в отдельный перспективный кластер республики, потому что Казахстан имеет потенциал развития данного кластера.

Bblвoдbl: В статье рассмотрены проблемы и перспективы развития инвестиционной политики в туристической отрасли. Авторами определены основные направления участия государства в инвестиционном процессе, которые нацелены на развитие туристической сферы. Авторы проанализировали научные подходы по определенным проблемам развития и функционирования туристической отрасли. Сформированы выводы о возможности применения зарубежного опыта в туристической отрасли Казахстана.

Ключевые слова: туристическая отрасль, туристический бизнес, туристическая инфраструктура, турагентство, транснационализация, государственная инвестиционная политика.

\section{References}

Airey D. Tourism policy-making in Australia: a national and state perspective/ D. Airey, \& L. Ruhanen, // Tourism Planningand Development. — 2014. — 2. — P. 149-162.

Chang W. A literature review of tourism management (1990-2013): a content analysis perspective / W. Chang, J.M. Katrichis // Current Issues in Tourism. - 2016. - 19. — P. 791-823.

Fayos-Solà. «Tourism Policy and Governance for Development», Tourism as an Instrument for Development / E. Fayos-Solà, M.D. Alvarez // A Theoretical and Practical Study. Bridging Tourism Theory and Practice, Vol. 5, Emerald Group Publishing Limited. - 2014. - 3. - P. 101-124.

Harris, R. (2018) The 2018 Green report. Hotelier. — (URL: https://www.hoteliermagazine.com/the-2018green-report).

Helmy E.M. «Political Uncertainty», Tourism as an Instrument for Development / E.M. Helmy // A Theoretical and Practical Study. Bridging Tourism Theory and Practice. — 2014. — 2. — P. 301-315.

Official site of Green Key Global (2020)._- (URL: https://www.greenkey.global/).

Official site of Leef life (2020). - (https:/ecounion.ru/wp-content/uploads/2019/12/sredstvarazmeshenia.pdf).

Official site of Radisson Hotel Group. - (https:/www.radissonhotelgroup.com/responsible-business_thinkplanet).

Official site of the United Nations. un.org. Retrieved from URL: https://www.un.org/sustainabledevelopment/

Pathirana. Tourist Harassment at Cultural Sites in Sri Lanka / D.P.U.T. Pathirana, W.K.A.C. Gnanapala, // Tourism, Leisure and Global Change. — 2015. - 5. — P. 42-56.

Rozo Bellón E. «Tourism in Colombia», Tourism as an Instrument for Development: A Theoretical and Practical Study / E. RozoBellón, L. Garavito González // Bridging Tourism Theory and Practice. — 2014. - 5. - P. 211-226.

Ruhanen L.«Indigenous Tourism and Events for Community Development in Australia», Tourism as an Instrument for Development: A Theoretical and Practical Study / L. Ruhanen, M. Whitford // Bridging Tourism Theory and Practice. — 2014. - 5. - P. 183-194.

Sainaghi R. Complexity traits and dynamics of tourism destinations / R. Sainaghi, R.Baggio // Tourism Management. - 2017. - 63. - P. 368-382.

The Global Ecolabelling Network (2017), 28-29. - (https://view.publitas.com/global-ecolabellingnetwork/gen-annual-report-2017/page/1).

Нижегородцев Р.M. Экологические стандарты в сфере туризма: проблемы внедрения / Р.М. Нижегородцев, С.В. Ратнер // Российское предпринимательство — Российский бизнес. 2015. - 13. - C. 2101-2124. 